УДК [616-89.843:[364-786:008]]:[616.89-008.1:159.944.4]

ШЕВЧЕНКО О. М.

http://orcid.org/0000-0003-0734-6533

https://doi.org/10.33577/2313-5603.36.2021.259-272

\title{
РОЗВИТОК ВОГНЕМЕТНИХ ТАНКІВ В СРСР І НІМЕЧЧИНІ ПІД ЧАС ДРУГОЇ СВІТОВОЇ ВІЙНИ
}

У статті висвітлено досвід створення в СРСР і Німеччині вогнеметних танків у період Другої світової війни. Розкрито еволюцію танкових вогнеметів від пневматичних (струменевих) до порохових автоматичних. Показано напрями вирішення проблем збільшення дистанції вогнеметання створенням в'язких запалювальних сумішей і використанням сили тиску порохових газів, підвищення вогневої міці танків встановленням вогнемета поряд з артилерійським озброєнням, а також забезпечення їх захищеності шляхом встановлення вогнеметів на танки 3 потужною бронею. У праці зазначається, що розглянутий досвід створення та застосування вогнеметних танків СРСР і Німеччини є важливим для розвитку української воєнно-історичної науки.

Ключові слова: Друга світова війна, запалювальна зброя, вогнеметний танк, автоматичний танковий вогнемет.

Постановка проблеми. Друга світова війна (1 вересня 1939 2 вересня 1945 рр.), як свідчить досвід, обумовила розроблення більш сучасних засобів для ураження вогнем військ та об'єктів противника, що широко і у великих масштабах застосовувалися практично усіма протиборчими сторонами в наступальних $\mathrm{i}$ оборонних діях (Ардамев, 2001: 49). Під час цієї війни також еволюціонували, порівняно 3 Першою світовою війною (Шевченко, 2021b: 35-38) і міжвоєнним періодом (Шевченко, 2021a: 18-23), танкові вогнемети i, відповідно, вогнеметні танки. На нашу думку, для розвитку української воєнноісторичної науки, передусім в умовах сьогодення, $є$ потреба розуміння процесу розвитку озброєння і військової техніки у різні історичні епохи і в різних країнах. Отже, дослідження проблематики розвитку танкових вогнеметів і вогнеметних танків СРСР і Німеччини - основних учасників німецько-радянської війни, є важливим науковим завданням. Обрана автором проблематика пов'язана із розробленням перспективних програм /

Шевченко Олексій Миколайович, перший заступник начальника Національної академії сухопутних військ імені гетьмана Петра Сагайдачного, м. Львів

(C) Шевченко О. М., 2021 
робочих програм навчальних дисциплін «Воєнна історія» для підготовки курсантів усіх ВВНЗ, що виконується у Національному університеті оборони України ім. Івана Черняховського (Протокол засідання секиії Воєнно-наукової ради..., 2021: 7), а також «Ітсорія озброєння та військової техніки», яка викладається у Національній академії сухопутних військ ім. гетьмана Петра Сагайдачного (Силабус навчальної дисципліни..., 2020; Програма начальної дисиипліни..., 2020).

Mema cmammi. Розкрити досвід створення в СРСР і Німеччині вогнеметних танків у період Другої світової війни.

Аналіз останніх досліджень та публікацій. Аналіз знайденої літератури за темою дослідження засвідчив, що проблематика розвитку вогнеметних танків в СРСР і Німеччині висвітлюється в сучасній зарубіжній, передусім російській, історіографії. Це праці А. Ардашева та С. Федосєєва, В. Братченка, М. Коломийця, Ю. Пашелюка, Д. Петрова, К. Рябова та інших. У західноєвропейській історіографії зазначену тему досліджували Д. Беккет, П. Чемберлен та інші. Водночас досить широко тема висвітлюються у науково-популярній і популярній літературі, відеофільмах тощо, науковість яких є дискусійною, а також є предметом жвавих аматорських обговорень на різних спеціалізованих сайтах i форумах. Таким чином вищезазначене актуалізує потребу у такому дослідженні.

Методи дослідження. Методологічною основою дослідження стали загальнонаукові принципи історизму, об'єктивності, системності, детермінізму та діалектичної єдності історичного і логічного. Вони реалізовані через використання загальнонаукових методів наукового пізнання: узагальнення, аналізу і синтезу, логічного, хронологічного, періодизації, а також спеціальних методів історичного дослідження, зокрема: історико-генетичного, історикопорівняльного. Поєднання названих методів наукового дослідження при всебічному аналізі джерел і літератури дозволило реалізувати визначену мету.

Виклад основного матеріалу дослідження. Під час Другої світової війни серійне будівництво вогнеметних танків було налагоджено у 8 країнах, зокрема Австралії, Великобританії, Італії, Канаді, Німеччині, СРСР, США та Японії. У кожній із цих країн були свої особливості, обумовлені технологічними можливостями, 
характером бойових дій та умовами театру воєнних дій. Знайдені відомості надали можливість встановити орієнтовну чисельність вогнеметних танків, їх типів і модифікацій, що використовувалися вищезазначеними державами під час Другої світової війни, зокрема: Австралія - 25 танків, типів / модифікацій - 1/2; Великобританія - 875 (5/6); Італія - 405 (2/2); Канада - 10 (1/1); Німеччина 692 (6/6); СРСР - 2808 (9/10); США - 137 (3/3); Японія - 8 (1/1). Наведені дані $є$ неповними, оскільки невідомою $є$ чисельність машин, що виготовлялися польовими майстернями із серійних танків чи бронемашин (Огнеметные танки, 2017).

Досліджуючи розвиток вогнеметних танків зазначимо, що на цей процес вплинуло створення більш технологічних танкових вогнеметів, якими озброювалися танки. Так, до кінця 1930-х років дальність викидання струменя до 90 м (за сприятливих умов), якої досягли пневматичні вогнемети, вже не відповідала умовам сучасного бою, оскільки потребувала підходу танків майже впритул до оборонних позицій противника, озброєного протитанковими засобами. Проблема підвищення дистанції вогнеметання почала вирішуватися створенням в'язких запалювальних сумішей і використанням замість сили стисненого повітря більш високого тиску порохових газів. Вже безпосередньо під час війни відбулася заміна танкових пневматичних вогнеметів на порохові, які були компактнішими, дозволили збільшити дистанцію вогнеметання, швидкострільність і високу автоматизацію i, найголовніше, зберегти артилерійське озброєння танка, що збільшувало його вогневу міць. Прикладом такого вогнемета може слугувати пороховий автоматичний танковий вогнемет АТО-41 (рос. А.Т.О. Автоматический Танковый Огнемет), розроблений в СРСР у 1941 р. і прийнятий на озброєння вогнеметних танків КВ-1, КВ-3, T-34 і Т-50. Дистанція вогнеметання АТО-41 (після модернізаціїАТО-42) становила до 110 - 130 м (Коломиец, 2007: 81; Постановление Совета Народных Комиссаров Союза ССР $i$ Центрального Комитета ВКП (б) от 13 марта 1941 г. №525224сс.; Пашолок, 2021).

Досвід радянсько-фінляндської війни 1939 - 1940 рр. і перших місяців німецько-радянської війни висвітлив потребу створення вогнеметних танків на базі захищених сильною бронею машин. В СРСР ця проблема почала вирішуватися шляхом монтажу на 
башту і корпус танків додаткових броньованих екранів. Проте це мало лише частковий ефект і обумовило розпочати роботи зі встановлення вогнеметів на добре захищені бронею танки Т-34 i КВ (броня ОТ-34: лобова - 45 мм (екран), бортова - 45 мм; броня КВ-8: лобова - 75 мм + 20 (екран), бортова - 75 мм (Танки. Альбом, 1945: 11, 16; Постановление Совета Народных Комиссаров Союза ССР і Центрального Комитета ВКП (б) от 13 марта 1941 г. №525-224cc.; Постановление СНК СССР и ЦК ВКП(б) от 15 марта 1941 2. № 548-232сс.; Коломиеи, 2007: 81; Ротмистров, 1975: 25-26; ТО-34, 2018). Серійний випуск вогнеметного танку під позначенням ТО-34 (або Т-О-34) почався наприкінці 1942 р. До початку 1944 р. зібрано 1170 од. різних варіантів або біля 3,3\% від загального числа випущених Т-34. Танк OT-34 став найбільш масовим вогнеметним танком Другої світової війни (Ардашев \& Федосеев, 2005; ТО-34. Средний огнеметный танк, 2018). На відміну від лінійного танка, ТО-34 був озброєний вогнеметом АТО-41 (від 1943 р. - АТО-42), розташованим на лобовому листі корпусу танка, праворуч від механіка-водія в броньованій кульовій установці курсового кулемета ДП, що дозволило зберегти 76-мм гармату (Танки. Альбом, 1945: 16).

Незручності у застосуванні вогнеметів, передусім в умовах боїв у місті (обмежені кути обстрілу), а також складнощі, що виникали у механіка-водія у бою під час одночасного керування танком i вогнеметом, обумовили потребу модернізації танка ТО-34. Тому, у травні 1944 р. з'явилася вогнеметна версія танка Т-34-85 - вогнеметний танк ОТ-34-85, в якому кути наведення вогнемета ATO-42 у вертикальній площині становили від -2 до $+10^{\circ}$, у горизонтальній $- \pm 15^{\circ}$. Слід зазначити, що важливою рисою танків ОТ-34 i OT-34-85 була їх майже повна зовнішня схожість із лінійними бойовими танками, збереження основних бойових характеристик базового танка та наявність засобів зв'язку. Як і лінійні, вогнеметні танки для постановки завіси забезпечувалися димовими шашками. Недоліками були відсутність кругового вогнеметання, малий сектор обстрілу по вертикалі й обмежена можливість ведення прицільного вогню з вогнемета. По суті, це були лінійні танки 3 додатковим вогнеметним озброєнням (Огнеметный танк TO-34..., 2020). Загалом було побудовано 331 танк ОТ-34-85: 1944 p. - 30, 1945 p. - 301. Тобто вогнеметні танки ОТ-34-85 
склали близько $1,4 \%$ від загальної кількості випущених за час війни танків Т-34-85. Вони перебували на озброєнні Радянської Армії до кінця 1950-х років, коли були замінені вогнеметними танками ОТ-54 і ОТ-55, в яких вогнемети встановлювалися у башті замість спарених кулеметів (Огнеметный танк ТО-34..., 2020; ТО-34. Средний огнеметный танк, 2018).

Влітку 1941 р. на базі танку КВ-1, який мав гарний броньований захист і містке бойове відділення, був розроблений дослідний зразок вогнеметного танка, що отримав індекс КВ-6, «Об’єкт 226» (КВ-6, 2015). Від лінійного танка він відрізнявся тільки установкою вогнемета АТО-41 у лобовому листі корпусу танка на місці курсового кулемета ДП, і 110-літровим баком із запалювальною сумішшю, розміщеним у бойовому відділенні. Зазначимо, що були й інші варіанти встановлення вогнемета, зокрема на правій надгусеничній полиці, по шість одиниць на танк (по три на кожній надгусеничній полиці) тощо, але вони не отримали подальшого розвитку (Коломиеи, 2001).

У листопаді 1941 р. розроблено дещо полегшений варіант танка 3 вогнеметним озброєнням - КВ-8 («Об'єкт 228», прийнятий на озброєння Червоної Армії постановою ДКО від 06.01.1942 p. № 1110 cс, серійно випускався у 1942 - 1943 рр.). Однак, на КВ-8 вогнеметна установка АТО-41 встановлювалась у башті замість штатної 76,2-мм гармати. Додатковим озброєнням були встановлені у башті кулемет ДП і 45-мм гармата зр. 1932/38. Ці заходи помітно знизили ефективність боротьби з ворожою бронетехнікою, але дозволили вести вогнеметання по круговому сектору $\left(360^{\circ}\right)$. Кут піднесення АТО-41 становив $+20^{\circ}$, кут зниження - $-20^{\circ}$. Для того, щоб зовні вогнеметний танк не відрізнявся від лінійних, 45-мм гармату зовні замаскували тонким хибним кожухом, що імітувало штатну 76,2-мм гармату. Основним призначенням КВ-8 було придушення укріплених вогневих точок (дотів, дзотів), знищення живої сили, танків і бронеавтомобілів противника тощо (Акт осмотра и испытания практической стрельбой опытных образцов танков КВ-7 и КВ-8..., 1942: 2-3; КВ-8. Тяжельй огнеметный танк, 2018).

Навесні 1942 р. почалося формування окремих вогнеметних танкових батальйонів, на комплектування яких надходили ТО-34 i КВ-8. Кожен такий батальйон включав: управління, три танкових роти (дві КВ-8 по 5 машин і одна ОТ-34), взводи забезпечення і 
господарського постачання, а також медичний пункт. Важка танкова рота складалася 3 двох взводів по два КВ-8 і КВ-8 (командирський) (512-й отдельнылй огнеметный танковылй Евпаторийский батальон, 2021; 516-й отдельный огнеметный танковый батальон, 2021). Підрозділи вогнеметних танків в основному діяли зі штурмовими батальйонами. Новим способом, породженим досвідом війни, стала тісна взаємодія танкових i ранцевих вогнеметів. Поєднання вогнеметних танків, що придушували i засліплювали вогневі точки противника, з портативними димовими засобами і ранцевими вогнеметами, що діяли з малих дистанцій, давало відчутний ефект у боях в населених пунктах i значно зменшувало втрати. При штурмі укріплених позицій великий результат досягався взаємодією вогнеметних танків 3 інженерними танками. У наступі вогнеметні танки розташовувалися у бойовому порядку зазвичай за лінійними танками, а при підході до об'єктів атаки (укріплень, будинків тощо) висувалися вперед і знищували вогнеметанням призначені цілі та випалювали зі споруд живу силу противника. У разі підходу вогнеметних танків до об'єкта вогнеметання на сприятливу дистанцію (до 100 м, а в лісистій місцевості - до 40-70 м) ефект дії вогнеметів як по ураженню противника, так і по моральному впливу на нього, був доволі високим (Организация и боевое применение советских огнеметных танковых частей..., 2021).

У Німеччині, яка є піонером у створенні і бойовому застосуванні піхотних ранцевих та великих траншейних вогнеметів, у міжвоєнному періоді практично не приділялося уваги розробленню самохідного вогнемета - вогнеметного танка. Діяльність у цій сфері розпочалася тільки з 1939 р. На 1 вересня 1939 р., на початок Другої світової війни, сухопутні війська Німеччини мали усього 3 легкі вогнеметні танки Pz.Kpfw.II Ausf.D/Pz. Kpfw.II (F), ще відомі як PzKpfw (Flammpanzer) II/Flamingo/ Sd.Kfz.122/Ausf D/E («Фламінго», за співзвучністю 3 flamme полум'я), створені на базі Pz.Kpfw. II (Panzerkampfwagen II, також відомим як Sd.Kfz. 121 i T-II). Замість стандартної башти на танк встановлювалася одномісна кулеметна башта 3 7,92-мм кулеметом MG.34 і приладами спостереження, а для самозахисту на кормі за бронекожухами - два димових гранатомети. Попереду на надгусеничних полицях монтувалися два поворотні вогнеметні брандспойти, що наводилися в межах сектора $180^{\circ}$. 
Усередині корпусу танка встановлено два резервуари для запалювальної суміші (бензин, загущений нафтою) по 180 л - по одному на кожен брандспойт, а в бронекожухах позаду вогнеметів - чотири балони зі стисненим азотом, під тиском якого викидалася запалювальна суміш. Дальність вогнеметання становила 35 - 40 м, кількість пострілів - до 80 по 2-3 або 3 - 5 с. Усього було побудовано 155 машин (Немецкий огнемётный танк Pz.Kpfw II Ausf.F Flamingo, 2018; Огнеметные танки / Германия, 2017).

За роки Другої світової війни німецька промисловість створила кілька зразків бронетехніки з вогнеметним озброєнням, які будувалися невеликими серіями. Тим не менш певним виключенням став самохідний вогнемет Sd.Kfz.251/16, виготовлений на базі бронетранспортера Sd.Kfz.251 Ausf.C. і прийнятий на озброєння в 1943 р. (за кілька років випущено 347 машин цього типу). Основним озброєнням танка були два 7-мм вогнемета Flammenwerfer aбо два 14-мм Flammenwerfer. Для захисту від обстрілу брандспойтів і вогнеметників встановлювалися броньовані щитки, а також екіпаж мав спеціальні вогнезахисні костюми. Конструкція вогнеметних установок дозволяла здійснювати їх наведення по горизонталі в межах сектора шириною $90^{\circ}$, та по вертикалі від $-10^{\circ}$ до $+40^{\circ}$. Дистанція викидання струменю залежала від способу застосування вогнеметів і складала до 50 - 55 м - одним вогнеметом і до 30 35 м - двома вогнеметами одночасно (Рябов, 2016a; Sd.Kfz 251-16 Flammpanzerwagen..., 2021; Огнеметание с бронетранспортера Sd. Kfz.251/16, 2018).

У Німеччині також розроблялися середні і важкі вогнеметні танки шляхом заміни гармати на вогнемет на САУ або лінійних танках, зокрема: у 1943 р. на базі CAУ «StuG»-StuG-III Fl Flamm ( StuG (Fl), 10 од. (вогнемет наводився на $10^{\circ}$ праворуч і ліворуч від нейтрального положення, а також міг змінювати кути вертикального наведення від $-6^{\circ}$ до $+20^{\circ}$; у 1944 р. на базі САУ «Hetzer»- Flammpanzer 38 (t) Hetzer, 20 од.; у 1943 р. на базі середнього танка PzKpfw III Ausf.M 3 посиленою лобовою бронею від 30 до 50 мм - PzKpftv-III (Fl) Sd.Kfz.141/3 (Flammpanzer III або Panzerflammwagen-III) (Рябов, 2016b; Рябов, 2016с; Чемберлен \& Дойл, 2008; Танк Т-ІІІ.., 2021; Огнеметная самоходка Sturmgesch\&252;tz, 2020; Ардашев \& Федосеев, 2005; Петров, 2019; Beckett, 2012). 
На початку війни під час Французької кампанії німецькі війська захопили 161 французький важкий танк «Char B-1» різних модифікацій, перейменованих в Pz/Kpfw. B2 740(f). 3 них близько 60 од. «Char B-1 Bis» у 1941 р., а пізніше - ще 36, були переобладнані у вогнеметні танки 3 індексом Flammwagen PzKpfw B-2(f) або Pz.Kpfw.B2 (Flamm). Вогнемет монтувався замість встановленої на корпусі 75-мм гаубиці. На відміну від багатьох німецьких вогнеметних машин, Flammwagen PzKpfw B-2(f) мали гармату - французьку 47-мм SA 35, що значно збільшувала вогневу міць. Ці вогнеметні танки, хоча і порівняно нечисленні, брали участь у великій кількості бойових дій від 1941 до 1944 р. на Східному фронті, зокрема під час прориву Перемишльського укріпленого району у Західній Україні (1941р.), у Криму (штурм м. Севастополь 1942 р.), а також у Свропі (в Югославії і Франції у 1944 р.). Проте, вони діяли із сумнівним успіхом: погано захищені вогневі точки ними ліквідувалися ефективно, але добре організовані укріплені райони придушували їх наступ (Flammpanzer B2 (f), 2019; Братченко, 2020).

Загалом озброєння німецьких танків вогнеметами значно збільшило їх бойову міць, оскільки ця зброя доповнила інші види вогню (артилерійський і кулеметний). Поєднанням бронетехніки і вогнеметів ще раз було підтверджено велику їх ефективність у прориві укріплених районів противника, зокрема у підтримці піхоти. Вони випалювали живу силу противника в окопах, щілинах і в дерево-земляних спорудах. Вогнеметна бронетехніка, особливо важка, у взаємодії з піхотою і саперами блокувала i придушувала найпотужніші доти. Слід зазначити, що як радянські, так і німецькі, вогнеметні машини у бою потребували додаткового потужного прикриття бронетехнікою і піхотою. Із урахуванням вогневої потужності і бойової ефективності такого прикриття потреба у застосуванні вогнеметних танків була сумнівною: танки і піхота могли б самостійно вести бій, не вдаючись до допомоги вогнеметних танків. Саме тому в Німеччині, на відміну від СРСР, вже у 1944 р. практично відмовилися від подальшого розроблення чи модернізації вогнеметних машин (Pz.Kpfw. B2 (Flamm) - german flamethrower with French roots, 2021).

Висновки та перспективи подальших досліджень. Таким чином, вищенаведене свідчить, що як в СРСР, так і в Німеччині під час Другої світової війни приділялася значна увага розвитку 
вогнеметних танків. Як і у міжвоєнному періоді, вони озброювалися поршневими вогнеметами, але з більш високими тактичними характеристиками.

Під час війни певним чином була вирішена проблема підвищення дистанції вогнеметання, зокрема створенням в'язких запалювальних сумішей і використанням замість сили стисненого повітря більш високого тиску порохових газів. Відбулася заміна танкових пневматичних вогнеметів на компактніші порохові, які дозволили збільшити дистанцію вогнеметання, швидкострільність і високу автоматизацію i, найголовніше, зберегти артилерійське озброєння танка. Загалом це збільшило вогневу міць танка.

Лідерство у цій сфері належало СРСР, де були розроблені поршневі автоматичні танкові вогнемети (АТО-41/АТО-42), які могли здійснювати вогнеметання згущеними сумішами до 110 130 м. Німецькі танкові вогнемети поступалися радянським зразкам: залежно від способу застосування вогнеметів дистанція складала до $50-55$ м.

Під час Другої світової війни в обох країнах почали встановлювати вогнемети на танки 3 потужною бронею, що значно підвищило захищеність машини і дозволило результативно їх використовувати у наступальних діях, зокрема проти добре укріплених фортифікаційних споруд і в умовах вуличних боїв.

Розглянутий досвід не втрачає свого значення і в сучасних умовах, що є важливим для української воєнно-історичної науки.

Можливими перспективними напрямами подальших наукових досліджень можуть бути: розвиток вогнеметних танків інших країн - учасниць Другої світової війни, зокрема Великобританії, США, Японії, Канади, Австралії та Італії; застосування вогнеметних танків провідних країн світу в оборонних і наступальних діях під час Другої світової війни.

\section{Використані посилання}

512-й отдельный огнеметный танковый Евпаторийский батальон (2021). Танковый фронт. URL: http://tankfront.ru/ussr/otb/otb512o.html [Дата звернення: 12.06.2021].

516-й отдельный огнеметный танковый батальон (2021) Танковый фронт. URL: http://tankfront.ru/ussr/otb/otb516o.html [Дата звернення: 12.06.2021].

Beckett, J. (2012) Flamming Panzer III. War History Online. URL: https://www.warhistoryonline.com/?p=2003 [Accessed date 07.05.2021]. 
Flammpanzer B2 (f): French Steel, German Fire (2019). War thunder. URL: https://forum.warthunder.com/index.php?/topic/469645-flammpanzer-b2-f-french-steelgerman-fire [Accessed date 14.07.2021].

Pz.Kpfw. B2 (Flamm) - немецкий огнемёт с французскими корнями. (2021) Pikabu. URL: https://pikabu.ru/story/pzkpfw_b2_flamm_nemetskiy_ognemyot_s_frantsuzskimi_kornyami_7394998 [Дата звернення: 12.06.2021].

Sd.Kfz 251-16 Flammpanzerwagen. Eastern Front, summer 1944. (2021). Postimage. URL: https://postlmg.cc/gLLr3ycV [Accessed date 17.05.2021].

Акт осмотра и испьтания практической стрельбой опытных образцов танков КВ-7 и КВ-8, изготовленных Кировским заводом. 05.01 .1942 г. (1942), 3 c. URL: http://www.russianarms.ru/forum/index.php/topic,14803.0.html [Дата звернення: 09.04.2021].

Ардашев А.Н., Федосеев С.Л. (2005). Огнемётнье танки Второй мировой войны. Москва, Моделист-конструктор. 64 с.

Ардашев А.Н. (2001) Огнеметно-зажигательное оружие: иллюстрированный справочник. Москва, ООО “Издательство Астрель”, ООО “Издательство АСТ”. 288 c.

Братченко В. (2020) Огнеметные танки США и Европы. Наука и техника. URL: https://naukatehnika.com/ognedyishashhie-monstryi-2.html [Дата звернення 12.05.2021].

КВ-6 (“Объект 226”) - тяжёльй сапёрно-химический танк. (2015) URL: https://smolbattle.ru/threads/Огнеметные-танки.59586/ [Дата звернення: 19.07.2021].

КВ-8. Тяжелый огнеметный танк (2018) AviArmor. URL: http://aviarmor.net/ tww2/tanks/ussr/kv8.htm [Дата звернення: 12.06.2021].

Коломиец М.В. (2001) История танка КВ. Фронтовая иллюстращия. № 5.77 с.

Коломиец М.В. (2007) Легкие танки БТ. “Летающий танк” 1930-х. Москва, Яуза, Стратегия КМ, ЭКСМО, 96 с.

Немецкий огнемётный танк Pz.Kpfw II Ausf.F Flamingo (2018) Feldgrau.Info. URL: http://feldgrau.info/2010-09-02-14-48-28/19216-podborka-foto-494 [Дата звернення: 14.07.2021].

Постановление Совета Народных Комиссаров Союза ССР і Центрального Комитета ВКП (б) от 13 марта 1941 г. № 525-224cc. «О вооружении огнеметных танков КВ, Т-34 и Т-50 (1941) URL: http://www.wartanks.ru/raznoe/prinimaetsyapostanovlenie-soveta-narodnix-komissarov-sssr.html [Дата звернення: 11.06.2021].

Постановление СНК СССР и ЦК ВКП(б) от 15 марта 1941 г. № 548-232cc. «О производстве танков КВ на 1941 г.». URL: https://istmat.info/node/58556 [Дата звернення: 18.07.2021].

Огнеметание с бронетранспортера Sd. Kfz.251/16. (2018). War Thunder. URL: https://forum.warthunder.ru/index.php?/topic/247818-sdkfz2343/ [Дата звернення: 17.08.2021].

Огнеметная самоходка Sturmgesch\&252; tz (Flamm) (2020). URL: https://ok.ru/group 53101222690990/topic/151342871261358 [Дата звернення: 16.08.2021].

Огнеметные танки. Германия (2017) Всё о Второй мировой. URL: https://wwii.space/ognemetnyie-tanki-germaniya/ [Дата звернення: 16.08.2021].

Огнеметные танки (2017) Все о Второй мировой. URL: https://wwii.space/ognemetnyie-tanki/ [Дата звернення: 16.08.2021]. 
Огнеметный танк ТО-34 [техника Музея “Битва за Ленинград” им. 3.Г. Колобанова] (2020) URL: https://www.youtube.com/watch?v=wcRf0wZIRwY [Дата звернення: 11.09.2021].

Организация и боевое применение советских огнеметных танковых частей и подразделений в годы Великой Отечественной Войны (2021) URL: https://ww2history.ru/combat_use_OT.html [Дата звернення: 16.08.2021].

Пашолок Ю. (2021) Огнедымашчй T-50. URL: http://alternathistory.com/yurij- pasholok- ognedyshashhij-t-50/ [Дата звернення: 06.07.2021].

Петров Д. (2019) Огнеметные КB. URL: https://zen.yandex.ru/media/id/5c1f35d6a652fa00aaaa86a2/gnemetnye-kv-5c434b1bb5d4ce00ae73ad4e [Дата звернення: 13.07.202o1].

Програма начальної дисципліни "Історія озброєння та військової техніки” (2020) Львів, НАСВ. 26 с.

Протокол засідання секиї Воєнно-наукової ради Міністерства оборони України за проблематикою Збройних Сил України від 13.04.2021 р. №3 (2021), 7 арк.

Ротмистров П.А. (1975). Танки на войне. Москва, ДОСААФ. 95 с.

Рябов К. (2016а). Самоходный огнемет Sd.Kfz.251/16 (Германия). Военное обозрение. URL: https://topwar.ru/95744-samohodnyy-ognemet-sdkfz25116-germaniya.html [Дата звернення: 16.08.2021].

Рябов К. (2016b). Огнеметная самоходка Sturmgeschütz (Flamm), Германия. Военное обозрение. URL: https://topwar.ru/95577-ognemetnaya-samohodkasturmgeschtz-flamm-germaniya.html [Дата звернення: 16.08.2021].

Рябов К. (2016c) Тяжелый огнеметный танк Flammwagen auf Pz.Kpfw. B2(f), Германия. Военное обозрение. URL: https://topwar.ru/95449-tyazhelyy-ognemetnyytank-flammwagen-auf-pzkpfw-b2f-germaniya.html [Дата звернення: 16.08.2021].

Силабус навчальної дисципліни "Історія озброєння та військової техніки” (2020) Львів, НАСВ. 14 с.

Танк T-III - Дальнейшая модернизация (танки L, M, N) (2021). Виртуальная Энииклопедия Бронетехники. URL: http://pro-tank.ru/bronetehnika-germany/srednietanki/143-t-3?start=2 [Дата звернення: 15.07.2021].

Танки. Альбом. (1945) Научно-Испытательный Бронетанковый Полигон ГБТУ Красной Армии, 56 c. URL: https://t34inform.ru/photo/photo_Album_NIBP1945.html [Дата звернення: 16.07.2021].

TO-34. Средний огнеметный танк (2018) AviArmor. URL: http://aviarmor.net/tww2/tanks/ussr/ot34.htm [Дата звернення: 14.08.2021].

Чемберлен П., Дойл Х. (2008) Полный справочник немецких танков и самоходных орудий Второй мировой войны. Москва, АСТ: Астрель. 274 с.

Шевченко О.М. (2021а) Еволюція запалювальної зброї та ії застосування у воєнних конфліктах міжвоєнного періоду (1918-1939). The Scientific Heritage : the journal publishes scientific studies. Budapest (Hungary). № 72 (Vol. 5). P. 18-23.

Шевченко O.M. (2021b) Створення та застосування вогнеметних танків у першій половині XX століття. Досвід застосування збройних сил у світових війнах $i$ воєнних конфліктах $X X$ - початку XXI cm.: тенденції та закономірності: матеріали міжвузівського науково-практичного семінару, 20.05. 2021 р., Вип.10. Київ, ЦП “Компринт”, С. 35 - 38. 


\section{References}

512th separate flamethrower tank Evpatoria battalion (2021). Tank front. URL: http://tankfront.ru/ussr/otb/otb512o.html [Дата звернення 12.06.2021].

516th separate flamethrower tank battalion (2021) Tank front. URL: http://tankfront.ru/ussr/otb/otb516o.html [Дата звернення: 12.06.2021].

Beckett, J. (2012) Flamming Panzer III. War History Online. URL: https://www.warhistoryonline.com/?p=2003 [Accessed date 07.05.2021].

Flammpanzer B2 (f): French Steel, German Fire (2019). War thunder. URL: https://forum.warthunder.com/index.php?/topic/469645-flammpanzer-b2-f-frenchsteel-german-fire [Accessed date 14.07.2021].

Pz.Kpfw. B2 (Flamm) - german flamethrower with French roots. (2021) Pikabu. URL: https://pikabu.ru/story/pzkpfw_b2_flamm_nemetskiy_ognemyot_s_frantsuzskimi_ kornyami_7394998 [Дата звернення: 12.06.2021].

Sd.Kfz 251-16 Flammpanzerwagen. Eastern Front, summer 1944. (2021). Postimage. URL: https://postlmg.cc/gLLr3ycV [Accessed date 17.05.2021].

Inspection certificate and practical shooting tests of prototypes of $K V-7$ and $K V-8$ tanks manufactured by the Kirov plant. 05.01.1942 (1942), 3 p. URL: http://www.russianarms.ru/forum/index.php/topic,14803.0.html [Дата звернення: 09.04.2021].

Ardashev A., Fedoseev S. (2005) Flamethrower tanks of World War II. Moscow, Model constructor. $64 \mathrm{p}$.

Ardashev A. (2001) Flamethrower Incendiary Weapons: An Illustrated Handbook. Moscow, LLC “Astrel Publishing House”, LLC “AST Publishing House”, 288 c.

Bratchenko V. (2020) Flamethrower tanks of the USA and Europe. Science and technology. URL: https://naukatehnika.com/ognedyishashhie-monstryi-2.html [Дата звернення: 12.05.2021].

KV-6 ("Object 226") - heavy engineer-chemical tank. (2015) URL: https://smolbattle.ru/threads/Огнеметные-танки.59586/ [Дата звернення: 19.07.2021].

KV-8 Heavy Flamethrower Tank (2018) AviArmor. URL: http://aviarmor.net/tww2/tanks/ussr/kv8.htm [Дата звернення: 12.06.2021].

Kolomiets M. (2001) History of the KV tank. Frontline illustration. № $5.77 \mathrm{c}$.

Kolomiets M. (2007) Light tanks BT. "Flying Tank" of 1930s. Moscow, Yauza, KM Strategy, EKSMO, 96 c.

German flamethrower tank Pz.Kpfw II Ausf.F Flamingo (2018) Feldgrau.Info. URL: http://feldgrau.info/2010-09-02-14-48-28/19216-podborka-foto-494 [Дата звернення: 14.07.2021].

Resolution of the Council of People's Commissars of the USSR and the Central Committee of the CPSU (b) dated March 13, 1941 No. 525-224ss. "On the armament of the KV, T-34 and T-50 flamethrower tanks (1941) URL: http://www.wartanks.ru/raznoe/prinimaetsya-postanovlenie-soveta-narodnixkomissarov-sssr.html [Дата звернення: 11.06.2021].

Resolution of the Council of People's Commissars of the USSR and the Central Committee of the All-Union Communist Party of Bolsheviks dated March 15, 1941, No. 548 232ss. "On the production of KV tanks for 1941" (1941) URL: https://istmat.info/node/58556 [Дата звернення: 18.07.2021]. 
Flamethrowing from an armored personnel carrier Sd. Kfz.251/16. (2018). War Thunder. URL: https://forum.warthunder.ru/index.php?/topic/247818sdkfz2343/ [Дата звернення: 17.08.2021].

Flamethrower self-propelled gun Sturmgesch\&252;tz (Flamm) (2020). URL: https://ok.ru/group53101222690990/topic/151342871261358 [Дата звернення: 16.08.2021].

Flamethrower tanks. Germany (2017) All about the Second World War. URL: https://wwii.space/ognemetnyie-tanki-germaniya/ [Дата звернення: 16.08.2021].

Flamethrower tanks. (2017) All about the Second World War, URL: https://wwii.space/ognemetnyie-tanki/ [Дата звернення: 16.08.2021].

Flamethrower tank TO-34 [equipment of The Z.G. Kolobanov Museum "Battle for Leningrad"] (2020) URL: https://www.youtube.com/watch?v=wcRf0wZIRwY [Дата звернення: 11.09.2021].

Organization and combat use of Soviet flamethrower tank units and subunits during the Great Patriotic War (2021) URL: https://ww2history.ru/combat_use_ OT.html [Дата звернення: 16.08.2021].

Pasholok Yu. (2021) Fire-breathing T-50. URL: http://alternathistory.com/yurijpasholok-ognedyshashhij-t-50/ [Дата звернення: 06.07.2021].

Petrov D. (2019) Flamethrower KV. URL: https://zen.yandex.ru/media/id/ 5c1f35d6a652fa00aaaa86a2/ognemetnye-kv-5c434b1bb5d4ce00ae73ad4e [Дата звернення: 13.07.2021].

The program of the discipline "History of armaments and military equipment" (2020) Lviv, National Army Academy, 26 c.

Record of the meeting of the section of the Military-Scientific Council of the Ministry of Defense of Ukraine on the issues of the Armed Forces of Ukraine dated April 13, 2021 № 3 (2021), 7 арк.

Rotmistrov P. (1975) Tanks at war, Moscow, DOSAAF, 95 c.

Ryabov K. (2016a) Self-propelled flamethrower Sd.Kfz. 251/16 (Germany), Military Review URL: https://topwar.ru/95744-samohodnyy-ognemet-sdkfz251-16germaniya.html [Дата звернення: 16.08.2021].

Ryabov K. (2016b). Self-propelled flamethrower Sturmgeschütz (Flamm), Germany, Military Review. URL: https://topwar.ru/95577-ognemetnaya-samohodkasturmgeschtz-flamm-germaniya.html [Дата звернення: 16.08.2021].

Ryabov K. (2016c) Heavy flamethrower tank Flammwagen auf Pz.Kpfw. B2 (f), Germany, Military Review, URL: https://topwar.ru/95449-tyazhelyy-ognemetnyytank-flammwagen-auf-pzkpfw-b2f-germaniya.html [Дата звернення: 16.08.2021].

Syllabus of the discipline "History of health and safety of technology" (2020) Lviv, National Army Academy, 14 c.

Tank T-III - Further modernization (tanks L, M, N) (2021). Virtual Encyclopedia of Armored Vehicles. URL: http://pro-tank.ru/bronetehnika-germany/srednie-tanki/143$\mathrm{t}-3$ ? start=2 [Дата звернення: 15.07.2021].

Tanks. Album. (1945) Scientific Testing Armored Range of the Main Armored Directorate of the Red Army, 56 p. URL: https://t34inform.ru/photo/photo _Album_NIBP-1945.html [Дата звернення: 16.07.2021].

TO-34. Medium flamethrower tank (2018) AviArmor. URL: http://aviarmor.net/tww2/tanks/ussr/ot34.htm [Дата звернення: 14.08.2021]. 
Chamberlain P., Doyle H. (2008) A Complete Guide to German Tanks and SelfPropelled Weapons of World War II. Moscow, AST: Astrel. 274 p.

Shevchenko O. (2021) Evolution of the burning weapon and its using in the interwar period military conflicts (1918-1939). The Scientific Heritage: the journal publishes scientific studies. № 72 (Vol. 5). P. 18 - 23.

Shevchenko O. (2021) Creation and application of flamethrower tanks in the first half of the twentieth century. Experience in the use of armed forces in world wars and military conflicts of the XX - early XXI centuries: trends and patterns: materials of the interuniversity scientific-practical seminar, 20.05.2021, Iss. 10. Kyiv, PH "Comprint", p. $35-38$.

\section{Shevchenko O. \\ DEVELOPMENT OF FLAMMING TANKS IN THE USSR AND GERMANY IN THE PERIOD OF THE SECOND WORLD WAR.}

The article highlights the experience of developing flame tanks in the USSR and Germany during the Second World War. The evolution of tank flamethrowers from pneumatic (jet) to automatic powder flamethrowers is revealed. The directions of solving the problems of increasing the range of flamethrowers by creating viscous incendiary mixtures and using the pressure force of powder gases, increasing the firepower of tanks by installing a flamethrower next to artillery, as well as ensuring their protection by installing flamethrowers on tanks with powerful armor. It is proved the above-mentioned measures drastically enhanced the security of tanks, their combat power, as far as flamethrowers complemented other types of fire (artillery and machine guns), permitting the vehicles to be employed efficiently in offensive operations, especially in the fortified areas and street combats. The research investigates the art of war in defensive and offensive operations utilizing flame tanks. The close interaction of tank and knapsack flamethrowers is noted as a new method generated by the experience of war. In the offensive, the combination of flamethrower tanks, which suppressed and blinded enemy firing points, using portable smoke devices and infantry knapsack flamethrowers which were operated from short distances, led to a tangible result in actions to support infantry and significantly reduced losses in both manpower and equipment. Simultaneously, the flamethrower armored vehicles, in particular the heavy ones, were usually located behind the battle tanks, consequently, while approaching an attack objective (fortifications, buildings, etc.) they advanced and destroyed the targets firing by flamethrowers and burned enemy manpower out of the buildings. It has been proved that research into the genesis of incendiary weapons and their use in military conflicts is important for Ukrainian military history.

Keywords: World War II, incendiary weapon, flame tank, automatic tank flamethrower 